\title{
DESAIN PARAMETRIK PADA PERANCANGAN DESAIN STUDI BENTUK BANGUNAN BERTINGKAT BANYAK
}

\author{
Hendro Trieddiantoro Putro ${ }^{1, *}$, Luhur Sapto Pamungkas ${ }^{2}$, \\ ${ }^{1} J u r u s a n$ Arsitektur, Fakultas Sains dan Teknologi, Universitas Teknologi Yogyakarta, \\ ${ }^{2} J u r u s a n$ Arsitektur, Fakultas Sains dan Teknologi, Universitas Teknologi Yogyakarta, \\ *hendro.trieddiantoro@gmail.com
}

\begin{abstract}
ABSTRAK. Melalui penelitian ini, peneliti menggunakan metode Desain Parametrik untuk studi bentuk bangunan bertingkat banyak. Rhinoceros dan Grasshopper digunakan sebagai alat studi bentuk bangunan bertingkat banyak. Desain parametrik dilakukan dengan parameter, yaitu berupa bentuk lantai dasar, jumlah lantai, ketebalan lantai, jarak antar lantai, derajat putar, dan olah bentuk. Eksperimen ditunjukkan dengan jumlah alternatif yang dihasilkan dari mengolah nilai parameter. Tujuan penelitian ini adalah mendapatkan gambaran proses mendesain bangunan berlantai banyak menggunakan metode desain parametrik. Hasil penelitian menunjukkan kreativitas dalam mengolah bentuk dasar menjadi bentuk bangunan bertingkat banyak.
\end{abstract}

Kata kunci: Desain Parametrik, Software Rhinoceros dan Grasshopper, Bangunan Bertingkat Banyak

ABSTRACT. The researcher has used the Parametric Design method to do form studies of a multistory building. The Rhinoceros and Grasshopper software have been used as a design tool. Design parameters were ground floor shapes, number of floors, the thickness of the story, the distance between levels, degree of rotation, and graph mapper. The experimental results are indicated by the number of alternatives generated from processing parameter values. The purpose of this study is to get a description of the process of designing many-story buildings using parametric design methods. The results of the study showed that creativity in processing basic forms into multistory buildings.

Keywords: Parametric Design, Rhinoceros and Grasshopper Software, Multi-storey Buildings

\section{PERAN TEKNOLOGI DALAM DESAIN}

Arsitek sebagai desainer lingkungan binaan tentunya merupakan profesi yang harus mempertimbangkan desain arsitektur dari aspek-aspek kompleks seperti yang telah disebutkan sebelumnya. Penggunaan teknologi digital secara umum di Indonesia saat ini masih populer sebatas visualisasi model $3 d$ virtual atau dijital. Keterbatasan yang ada pada software tersebut memunculkan potensi penggunaan teknologi dijital dalam bidang arsitektur masih belum sepenuhnya teraplikasikan. Menurut Szalapaj beberapa peran dari penggunaan teknologi dijital dalam bidang arsitektur adalah sebagai berikut[1] :

1. Sebagai alat bantu merepresentasikan desain arsitektur

2. Sebagai alat bantu simulasi

3. Sebagai alat bantu evaluasi

4. Sebagai jembatan antara proses perancangan ke tahap konstruksi

5. Sebagai penerjemah informasi dijital ke dalam proses pembangunan

\section{DESAIN KOMPUTASIONAL}

Desain komputasional atau umum disebut desain dijital merupakan sebuah terminologi luas yang merujuk pada beragam kegiatan dijital, mulai dari pemunculan desain hingga perhitungan struktur. Penggunaan definisi desain dijital atau desain komputasional yang paling biasa adalah pada penciptaan gambar visual menggunakan software. Beberapa kelebihan yang didapat dari menggunakan metode desain dijital menurut para peneliti adalah meningkatnya kemampuan dalam mengeksplorasi bentuk sehingga memunculkan alternatif desain yang lebih beragam serta meningkatkan kreativitas dalam detil arsitektural.

\section{DESAIN PARAMETRIK}

Sebagai alat bantu merepresentasikan desain arsitektur

Sebagrizathat bplanarsietrikasi merupakan sebuah

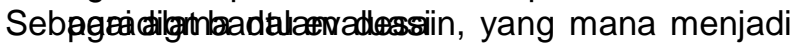
teknik atau cara dalam menyelesaikan

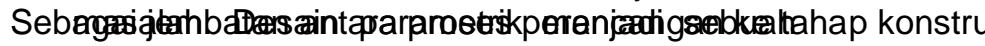
pemikiran fundamental dalam perancangan. Wassim Jabi dalam bukunya "Parametric

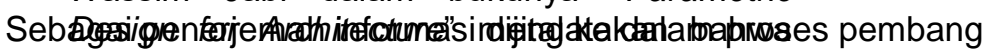
desain parametrik adalah proses desain berdasarkan pada pemikiran algoritmik yang memunculkan detil dari sebuah parameter, 
dimana parameter tersebut bersama - sama memperkuat dan memperjelas hubungan antara tujuan desain dan bagaimana cara desain tersebut akan merespon masalah[2]. Alat desain parametrik merupakan software yang memudahkan pengguna atau perancang untuk menspesifikasi hubungan antar beragam parameter dalam proses desain. Istilah 'parametrik' berasal dari matematika (persamaan Parametrik) dan mengacu pada penggunaan parameter atau variabel tertentu yang dapat diedit untuk memanipulasi atau mengubah hasil akhir dari sebuah persamaan atau sistem.

Desain parametrik berasal dari unsur-unsur elemen yang digunakan untuk memanipulasi dan menginformasikan desain, menjadi geometri dan struktur yang kompleks. Desain parametrik adalah proses desain berdasarkan pada pemikiran algoritmik yang memunculkan pola dari sebuah parameter, dimana parameter tersebut bersama sama memperkuat dan memperjelas hubungan antara tujuan desain dan bagaimana cara desain tersebut akan merespon masalah[2].

Desain parametrik bukanlah konsep baru dan selalu membentuk bagian dari arsitektur dan desain. Pertimbangan kekuatan perubahan seperti iklim, pengaturan, budaya, dan penggunaan selalu merupakan bagian dari proses desain. Bentuk pada parametric design tidak didefinisikan terlebih dahulu, melainkan digolongkan dalam template tertentu dan dikontrol berdasarkan parameter-parameter penentu. Oleh karena itu suatu desain yang baru dapat dihasilkan dari sebuah template dasar 'hanya' dengan memasukkan angkaangka parameter yang sesuai dengan data proyek tersebut [3].

\section{GENERATIVE ALGORITHM}

Generative algorithm merupakan sebuah metode desain yang berbasis logic thinking desainer dalam mengendalikan geometri untuk mendapatkan transformasi bentuk yang dibutuhkan dengan tools aplikasi Rhinoceros dan Grasshopper yang merupakan perangkat pendukungnya[4].

Menurut Khabazi, pada buku Generative algorithm, selain menggambar atau membuat objek 3d dijital, desainer dituntut untuk memahami aspek-aspek dasar geometri (umumnya matematika geometri) yang akan ditranslasikan ke dalam bentuk parameter angka atau persamaan matematik. Angka dan persamaan matematik tersebut menjadi langkah-langkah atau satu set aturan (algorithm) untuk membuat objek dalam ruang virtual. Satu objek yang terbentuk dari algoritma ini selanjutnya akan menjadi input dasar atau bahkan bentuk dasar yang dikenakan algoritma tersebut untuk menghasilkan bentuk selanjutnya. Proses ini dikenal sebagai proses "algorithmic". Sehingga setiap komponen atau bentuk yang muncul dari proses ini akan saling terhubung satu sama lain dan parameter yang menjadi generatornya[5].

\section{BANGUNAN BERTINGKAT BANYAK}

Beberapa ahli memberikan pendapat tentang Pengertian bangunan bertingkat banyak yaitu :

1. International Conference on Fire Safety in High-Rise Buildings mengartikan bangunan bertingkat banyak sebagai "struktur apapun dimana tinggi dapat memiliki dampak besar terhadap evakuasi."

2. New Shorter Oxford English Dictionary mengartikan bangunan tinggi sebagai "bangunan yang memiliki banyak tingkat"

3. Massachusetts General Laws mengartikan bangunan tinggi lebih tinggi dari 70 kaki (21 $\mathrm{m})$

4. Banyak insinyur, inspektur, arsitek bangunan dan profesi sejenisnya mengartikan bangunan tinggi sebagai bangunan yang memiliki tinggi setidaknya 75 kaki (23 m).

Tinggi rata-rata satu tingkat lantai adalah 13 kaki atau 4 meter. Jika suatu bangunan memiliki tinggi 79 kaki atau 24 meter, maka idealnya memiliki 6 tingkat.

\section{METODE PENELITIAN}

Studi bentuk bangunan bertingkat banyak dilakukan dengan eksperimen, yaitu mengeksplorasi varian melalui permodelan desain parametrik secara komputasi di grasshopper. Sugiyono mengatakan bahwa ciri khas penelitian eksperimen adalah adanya variabel kontrol. Variabel kontrol merupakan data parameter yang diatur oleh peneliti sehingga mempengaruhi variabel terikat[6].

Variabel kontrol pada penelitian ini adalah bentuk lantai dasar, jumlah lantai, ketebalan lantai, jarak antar lantai, derajat putar, dan olah bentuk. 
Tabel 1. Variabel Penelitian

\begin{tabular}{|l|l|c|c|}
\hline No. & \multicolumn{1}{|c|}{$\begin{array}{c}\text { Variabel } \\
\text { Terikat }\end{array}$} & Parameter & Indikator \\
\hline 1. & $\begin{array}{l}\text { Bangunan } \\
\text { Berlantai } \\
\text { Banyak }\end{array}$ & $\begin{array}{c}\text { Jumlah } \\
\text { lantai }\end{array}$ & Meter \\
\cline { 3 - 4 } & $\begin{array}{c}\text { Jarak antar } \\
\text { lantai }\end{array}$ & Meter \\
\cline { 3 - 4 } & $\begin{array}{c}\text { Ketebalan } \\
\text { lantai }\end{array}$ & Meter \\
\cline { 3 - 4 } & $\begin{array}{c}\text { Bentuk } \\
\text { bangunan }\end{array}$ & Volume \\
\hline
\end{tabular}

Alat penelitian yang digunakan pada penelitian ini berupa Rhinoceros dan Grasshopper. Parameter yang digunakan sebagai dasar pengembangan desain parametrik berupa jarak antar lantai, jumlah lantai, ketebalan lantai, dan bentuk bangunan. Jarak antar lantai, jumlah lantai, dan ketebalan lantai memiliki dimensi berupa meter, dimana Number slider digunakan untuk merubah nilai tersebut. Graph mapper digunakan untuk mengevaluasi bezier curve yang membentuk volume objek untuk merubah proporsi dan komposisi bentuk. Definisi desain parametrik dikembangkan dari penelitian Guidera[7], yaitu studi bentuk desain parametrik dilakukan dari kurva, kurva tersebut terdiri dari 3 bentuk dasar yaitu persegi, bulat, dan segitiga sama sisi.

\section{HASIL DAN PEMBAHASAN}

Bentuk lantai dasar yang digunakan yaitu berupa persegi, bulat, dan segitiga dibentuk pada software Rhinoceros.

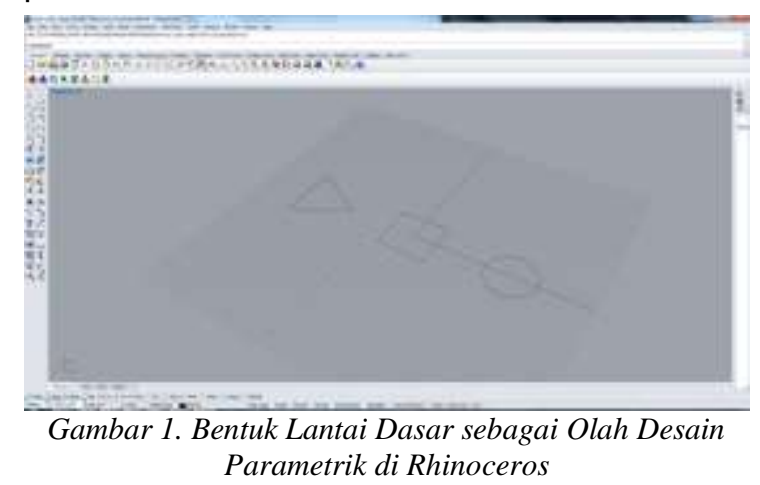

Langkah selanjutnya yaitu menyiapkan definisi pada grasshopper. Olah bentuk menggunakan kurva sebagai operasi awal. Operasi kurva merupakan objek yang berupa satu atau lebih garis lurus atau lengkung. Kurva dapat berupa garis menyambung atau tertutup.

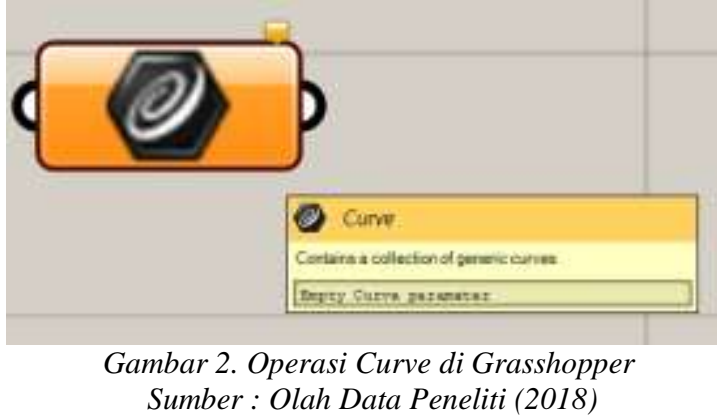

Operasi utama pada penelitian ini berupa move, rotate, scale, loft, serta extrude. Operasi move digunakan untuk mengatur parameter jarak antar lantai, dan jumlah lantai. Operasi rotate digunakan untuk mengatur parameter derajat putar. Operasi scale digunakan untuk mengatur parameter volume komposisi bentuk menggunakan operasi graph mapper. Operasi loft digunakan untuk memunculkan kulit bangunan dari bentuk yang terpilih. Operasi extrude digunakan untuk mengatur parameter ketebalan lantai.

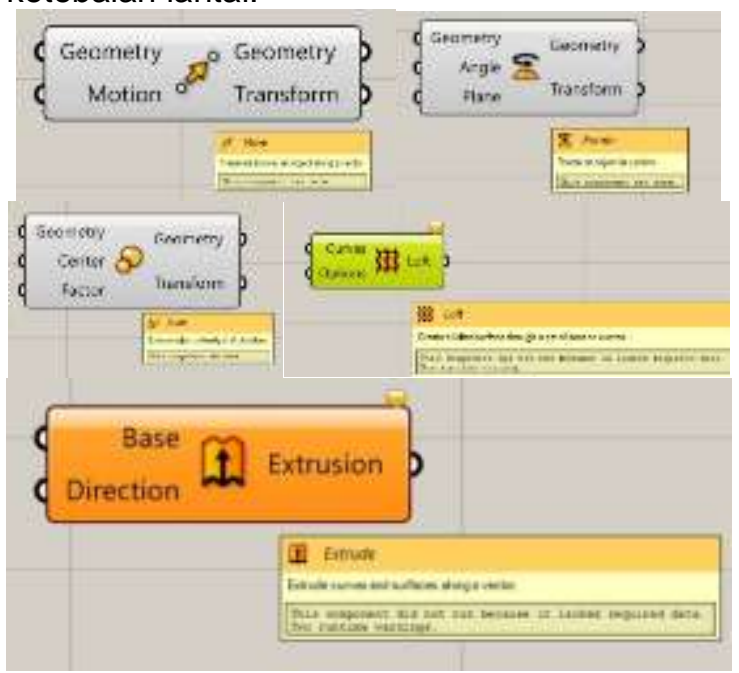

Gambar 3. Operasi Move, Rotate, Scale, Loft, dan Extrude

Sumber : Olah Data Peneliti (2018) 
Berikut daftar langkah operasi parameter di Grasshopper pada penelitian ini :

Tabel 2. Daftar Operasi pada Grasshopper
\begin{tabular}{|l|l|}
\hline No & Operasi Grasshopper \\
\hline 1 & Curve Geometry \\
\hline 2 & Series Number \\
\hline 3 & Series Degree \\
\hline 4 & Move Motion Z \\
\hline 5 & Rotate Radian \\
\hline 6 & Scale Factor Graph Mapper \\
\hline 7 & Loft curve \\
\hline 8 & Boundary Surfaces \\
\hline 9 & Extrude motion Z \\
\hline
\end{tabular} Sumber : Olah Data Peneliti (2018)

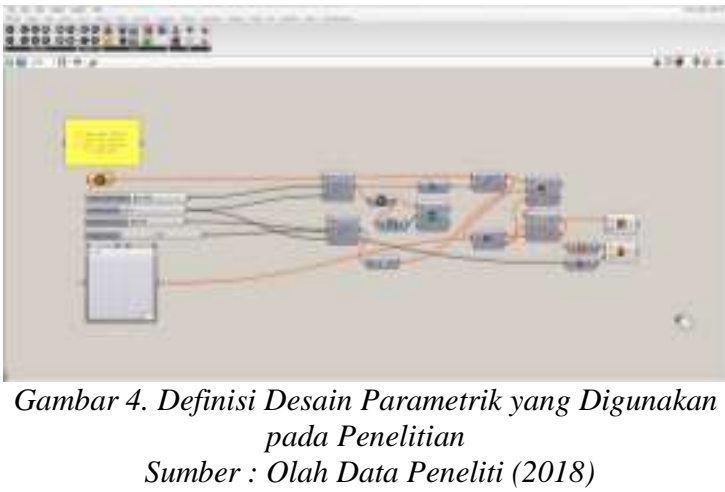

Eksperimen yang dilakukan adalah memilih salah satu dari 3 bentuk dasar yang tersedia di Rhinoceros dengan melakukan operasi set one curve di grasshopper. Bentuk dasar persegi yang dipilih terlihat pada gambar dibawah.

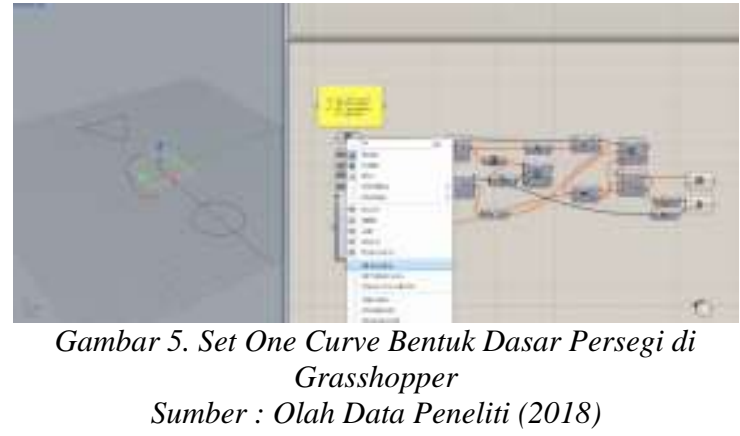

Langkah selanjutnya setelah memilih bentuk dasar kemudian mengatur parameter jarak antar lantai, jumlah lantai, dan ketebalan lantai. Dimensi jarak antar lantai dan ketebalan lantai adalah meter, serta jumlah lantai adalah berupa satuan. Dimensi gambar dibawah pada jarak antar lantai yaitu 4 meter dan berjumlah 10 lantai dengan ketebalan lantai 0,5 meter.

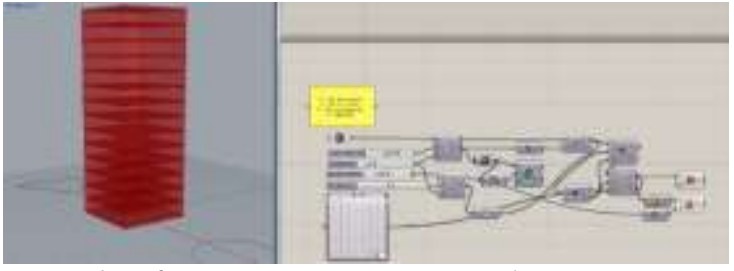

Gambar 6. Mengatur Parameter Jarak Antar Lantai, Jumlah Lantai, dan Ketebalan Lantai

Olah bentuk yang selanjutnya dilakukan dengan mengatur parameter derajat putar dan bentuk menggunakan graph mapper. Gambar dibawah berderajat 10 dengan graph mapper berbentuk lengkung satu sisi.

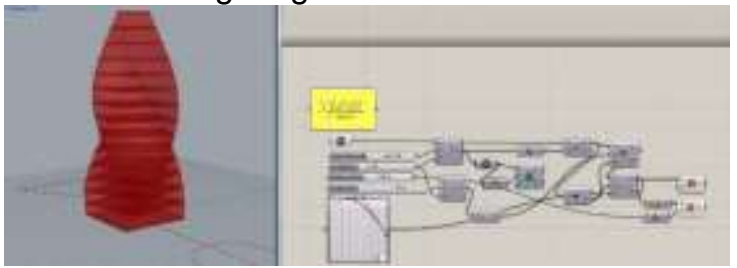

Gambar 7. Mengatur Parameter Derajat Putar dan Olah Bentuk Bangunan

Sumber : Olah Data Peneliti (2018)

Proses eksperimen diakhiri dengan menyimpan gambar hasil olah bentuk. Proses pencarian bentuk ini berlanjut selama 1 jam. Setiap alternatif hasil olah bentuk disimpan menjadi gambar. Gambar dibawah merupakan alternatif olah bentuk berderajat 10 dengan graph mapper berbentuk lengkung dua sisi.

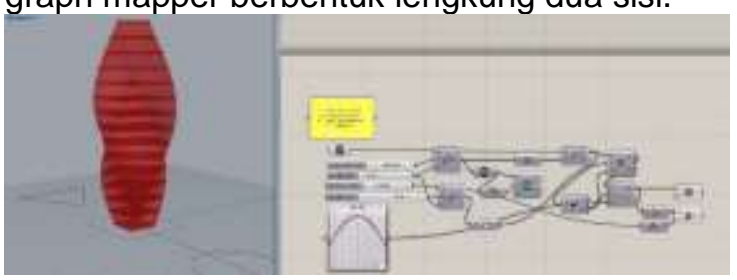

Gambar 8. Mengatur Parameter Derajat Putar dan Olah Bentuk Bangunan Lengkung 2 Sisi Sumber : Olah Data Peneliti (2018) 


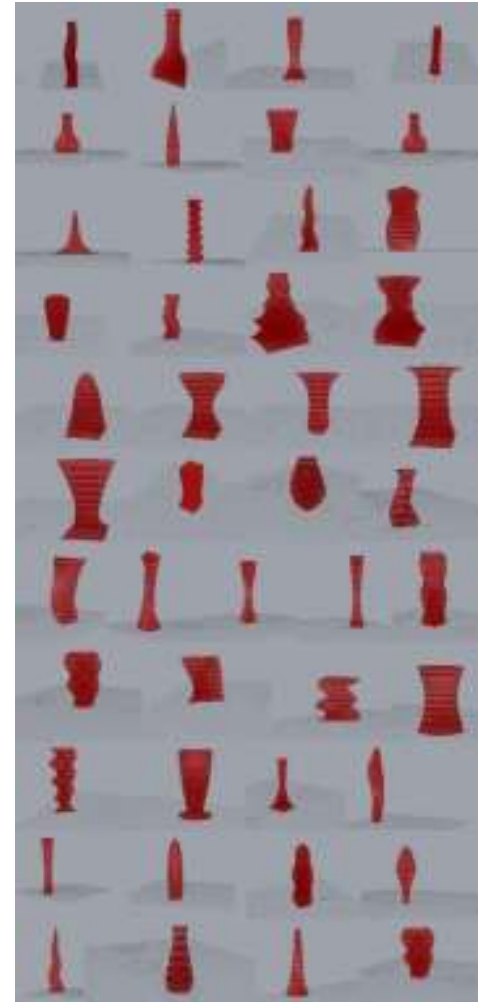

Gambar 9. Kompilasi Hasil Studi Bentuk Bangunan Bertingkat Banyak

Sumber : Olah Data Peneliti (2018)

Pieter dan Mandey dalam penelitiannya menjelaskan pada dasarnya parametric design adalah metode merancang objek arsitektural yang berdasarkan pada hubungan atau aturan atau algoritma dalam komputer[8]. Algoritma dalam arsitektur juga berhubungan dengan parametric design. Khabazi[5] dalam bukunya hal. 7 menjelaskan istilah algoritma yaitu

"An algorithm is a set of rules and instructions in a step by step procedure to calculate, process data and do a defined task"

Kalimat diatas dapat dipahami bahwa sebuah algoritma merupakan sebuah kumpulan aturan dan instruksi dalam prosedur bertahap untuk menghitung, memproses data, dan melakukan sebuah tugas dengan jelas. Seperti objek 3 dimensi pada gambar 9 , parameter pembentuk objek 3 dimensinya yaitu jarak antar lantai, jumlah lantai, ketebalan lantai, dan volume bisa digunakan sebagai variabel, dengan memasukkan angka yang berbeda, maka beragam bentuk akan terjadi. Hal inilah yang terjadi pada studi bentuk bangunan bertingkat banyak diatas, dengan memasukkan angka yang berbeda maka ragam bentuk akan terjadi.
Selama kurun waktu 1 jam, peneliti mendapatkan beragam bentuk bangunan bertingkat banyak. Schnabel[9], Anderson dan Tang[10], Wannan[11] menjelaskan kelebihan aplikasi metode desain parametrik dalam fase awal desain menggunakan software grasshopper adalah desainer memiliki kemampuan untuk bereksperimen dengan banyak desain dan membandingkan kemungkinan solusi berdasarkan satu faktor dengan faktor lainnya.

Ferdian dan Rukmi menyatakan bahwa salah satu permasalahan dari seorang desainer objek digital adalah lamanya proses eksplorasi bentuk geometri dari desain objek digital yang sudah diciptakan sementara jumlah permintaan desain dari konsumen sangat banyak sehingga memerlukan cara yang efektif dalam proses desain[12]. Ferdian dan Rukmi membuat desain parametrik secara konseptual, eksplorasi bentuk objek dapat dilakukan hanya dengan mengubah nilai parameter tanpa memulai desain dari awal. Komparasi proses transformasi objek yang sama dengan menggunakan software Google Sketchup membuktikan bahwa desain parametrik konseptual dengan metode generative algorithm lebih efektif dalam waktu yang dibutuhkan untuk proses esksplorasi bentuk geometri.

Suyoto et al menjelaskan dalam hasil penelitiannya terhadap metode desain parametrik sebagai alat pengambil keputusan dalam perencanaan dan desain bangunan tinggi kantor di Kebayoran Lama[13]. Suyoto et al mengatakan metode desain parametrik memberikan banyak keuntungan dibandingkan dengan cara tradisional dalam hal koordinasi pekerjaan secara simultan. Metode desain parametrik memeberikan banyak pilihan desain dan dapat memonitor perubahan desain secara langsung. Namun metode desain parametrik membutuhkan kemampuan logika yang baik dan membutuhkan waktu lebih. Serupa dengan penjelasan (Sanguinetti dan Kraus, bahwa mempelajari desain parametrik artinya termasuk mempelajari dan memahami algoritma secara mendalam tetapi bukan merupakan hal yang utama[14].

\section{KESIMPULAN}

Metode desain parametrik sebagai salah satu cara yang menarik untuk memunculkan alternatif gubahan bentuk bangunan bertingkat banyak. Parameter desain di grasshopper dirasa efektif dalam proses desain dan memudahkan eksplorasi bentuk, sehingga 
merubah objek dapat dilakukan hanya dengan merubah nilai parameter tanpa memulai desain dari awal.

Logika pemrograman dan algoritma memang diperlukan untuk memahami alur mendesain parametrik di rhinoceros dan grasshopper sehingga perlu waktu dan pembelajaran lebih detil.

\section{UCAPAN TERIMA KASIH}

Ucapan terimakasih ditujukan kepada Kementerian Riset, Teknologi Dan Pendidikan Tinggi. Dan Universitas Teknologi Yogyakarta

\section{DAFTAR PUSTAKA}

[1] Szalapaj, P. (2005). Contemporary Architecture and the Digital Design Process. Architectural Press.

[2] Jabi, W. (2013). Parametric Design for Architecture. London: Laurence King.

[3] Ugail, H. (2011). Partial Differential Equations for Geometric Design. Springer.

[4] Khabazi, M. (2009). Algorithmic Modelling with Grasshopper. London: Architectural Assosiation.

[5] Khabazi, Z. (2012). Generative Algorithm (Using Grasshopper). morphogenesism education.

[6] Sugiyono. (2011). Metode Penelitian Kuantitatif, Kualitatif, dan $R \& D$. Bandung: Alfabeta.

[7] Guidera, S. (2011). Conceptual Design Exploration in Architecture Using Parametric Generative Computing: $A$ Case Study. ASEE Annual Conference \& Exposition. Vancouver: ASEE. Retrieved from https://peer.asee.org/17649

[8] Pieter, D. W., \& Mandey, J. C. (2012, May). Algotecture (Algorithmic Architecture). Daseng: Jurnal Arsitektur DASENG UNSRAT Manado, Volume 1, No 1.

[9] Schnabel, M. A. (2007). Parametric Designing In Architecture. A Dong, A Vande Moere \& JS Gero (eds), CAADFutures'07, 237-250.

[10] Anderson, J., \& Tang, M. (2011). Form Follows Parameters Parametric modelling for fabrication and manufacturing processes. In N. G. C. M. Herr (Ed.), Circuit Bending, Breaking and Mending: Proceedings of the 16th International Conference on ComputerAided Architectural Design Research in Asia (pp. 91-100). Hongkong: Association for Computer-Aided Architectural Design Research in Asia (CAADRIA).

[11]Wannan, R. S. (2016). Teaching Parametric Design In Architecture. Imperial House Publishers (ASCAAD 2016 book of proceeding).

[12] Ferdian, Y. A., \& Rukmi, A. M. (2012). Desain Parametrik Konseptual Dengan Metode Generative Algorithm Dalam Eksplorasi Geometri Di Bidang Arsitektural Dan Desain Produk. Jurnal Sains Dan Seni Pomits.

[13] Suyoto, W., Indraprastha, A., \& Purbo, H. W. (2014, August 8-9). Parametric Approach as a Tool for Decisionmaking in Planning and Design Process. Case study: Office Tower in Kebayoran Lama. 5th Arte Polis International Conference and Workshop "Reflections on Creativity: Public Engagement and The Making of Place", Arte-Polis 5, 8-9 August 2014, Bandung, Indonesia, 328-337.

[14] Sanguinetti, P., \& Kraus, C. (2011). Thinking in Parametric Phenomenology. ACADIA Regional 2011 Conference. (pp. 39-48). Nebraska: University of Nebraska-Lincoln. 